\title{
Asset Write-offs: An Empirical Investigation of Timeliness
}

\author{
Tae H. Choi ${ }^{\mathrm{a}^{*}}$ \\ ${ }^{a}$ KDI School of Public Policy and Management
}

\begin{abstract}
Anecdotal evidence shows that managers have plenty of discretion to manage the timing of write-offs to take action related to earnings management. In this paper, I examine whether write-offs are recorded in a timely manner. In particular, I investigate the association between asset write-offs and the market return over a long window as a metric of testing the timeliness of write offs. The results suggest that write-offs are recorded in a less timely manner than other components of earnings.
\end{abstract}

JEL Classification: M40, M41, M49

Keywords: Write-off, aggregate earnings, aggregate return, timeliness of earnings, earnings management

\section{Introduction}

This paper examines the timeliness of accounting recognition of write-offs by investigating the association between earnings with negative special items and security markets. ${ }^{1}$ The increasing prevalence of write-off metrics of long-lived assets reflects the realization among managers, investors, academics, and regulators that the manner in which write-offs are handled has a greater impact on earnings, book values of assets, and security prices than they previously understood (Clifford, 2001). Evidence to date indicates that the Generally Accepted Accounting Principles (GAAP) allow firms

* Address: P.O. Box 184 Chungnyang, Seoul 130-868 Korea. Tel: 82-3299-1221. Fax: 82-3299-1240. Email: TChoi@KDIschool.ac.kr. This paper is based on a section of the author's PhD dissertation. The author wishes to thank his adviser, Peter Easton, for his professional guidance and support. The author also appreciates the contribution of his dissertation committee members, Richard Dietrich and Kirk Philipich. He expresses special thanks to Jinhan Pae for his invaluable insights and advice. The author gratefully acknowledges helpful comments from Siew Hong Teoh, Keji Chen, Greg Sommers, Randal Smith, Hyesun Lee, seminar participants at the Ohio State University, the KDI School of Public Policy, and an anonymous referee.

${ }^{1}$ Write-off is not exactly equivalent to special item. Special item is a broader term that encompasses other unusual or non-recursive accruals. Nevertheless, the financial press uses the terms interchangeably. 
great discretion over the magnitude and timing of write-offs. This flexibility leaves managers room to manage earnings. Realizing this, after the FASB issued statement No. 121, Accounting for the Impairment of Long-Lived Assets and for Long-Lived Assets to Be Disposed Of, the FASB released statement No. 144, Accounting for the Impairment of Disposal of Long-Lived Assets, requiring that asset write-offs should reflect contemporaneous information. Together, these issuances have brought to light measurement and timing issues pertaining to write-offs.

This study is an effort to track and record the measures companies employ to exploit the discretion the FASB has allowed them over the timing and magnitude of their writeoffs. Because FASB statement No. 144 grants firms discretion over the different lag times employed in the accounting recognition of write-offs, it is difficult for an observer to determine whether a write-off has been recorded in a timely manner. Concerning the magnitude of write-offs, many companies tend to overstate one-time write-offs in order to increase future earnings. In such cases, the market may react favorably to large writeoffs because a company's profit almost always improves sharply after large write-offs. ${ }^{2}$

Though extant literature documents the information content of write-off disclosures, there has been relatively little research on the measurement and timing issues associated with write-offs. In other words, studies have tried to determine the security price reaction to unexpected write-off amounts over shorter intervals (e.g., a two-day market adjusted return surrounding the announcement). The reasoning is that if a write-off decision is related to restructuring, the market may applaud the write-off as an effective management reaction to a bad business environment (e.g., the disposal of unprofitable segments and/or product lines of the business). In such cases, the stock market will show positive market adjusted return over the period surrounding the write-off announcement (Strong and Meyer, 1987; John and Ofek, 1995; Hogan and Jeter, 1998). On the other hand, should a write-off decision be viewed as being related to asset impairment without future prospects for improvement, market reaction to the write-off is negative (Elliott and Shaw, 1988; Elliott and Hanna, 1996). Be that as it may, whichever interpretation prevails, the majority of studies provide little evidence of a significant relation between market reaction and write-off disclosure (Zucca and Campbell, 1992; Bunsis, 1997; Bartov et al., 1998; Frances et al., 1997; Chaney et al., 1999). If anything, they show that market reactions to write-off announcements are mixed and unclear. At this point, a brief overview of the challenges involved with any study of write-offs is worthwhile insofar as it serves to provide context and at the same time, to articulate the variables one must take into account in developing the metrics required to accurately assess the full impact of the issue of timeliness in the recognition of write-offs.

Past studies have served to highlight the many difficulties in the information content study of write-offs. A case in point is the lack of timeliness in disclosing value relevant events. If a write-off is not announced in a timely manner, the write-off response coefficient on an unexpected write-off will not be significant or may merely capture value irrelevant noise. Indeed, the market might have made the adjustment long before

\footnotetext{
${ }^{2}$ According to SEC Chairman Arthur Levitt, "When earnings take a major hit, the theory goes Wall Street will look beyond a one-time loss and focus only on future earnings. And if these charges are conservatively estimated with a little extra cushioning, that so-called conservative estimate is miraculously reborn as income when estimates change or future earnings fall short." (Levitt, 1998)
} 
the write-off announcement. If write-off announcements are anticipated by the market, many event studies will produce spurious results due to noise deriving from information pertaining to the announcement. Such ambiguity calls into question whether or not a write-off has been recorded in a timely manner (Heflin and Warfield, 1997; Alciatore et al., 2000; Collins and Henning, 2000).

Another related issue is the leaking of information prior to write-off disclosures. In such cases, current quarter write-offs have been anticipated through various channels in previous periods.

It should be noted that the majority of event studies have disaggregated writeoffs (e.g., discretionary write-offs vs. nondiscretionary write-offs, restructuring vs. pure asset impairment, etc). Having mentioned that, disaggregating write-offs presents considerable challenges (Strong and Meyer, 1987; Wilson, 1996).

Yet a further complication related to asset write-offs, one which is delved into more deeply in section 4.2 below, is the different behavior exhibited by profit and loss firms. Investors first consider whether the firms make a profit or loss, then consider whether the firms meet or miss analysts' forecasts (Brown, 1999; DeGeorge, et al., 1999). DeGeorge et al. (1999) document three thresholds that drive earnings management: (1) to report profit; (2) to sustain current performance; and (3) to meet analysts' forecasts. Before assessing the impact of a write-off, investors first consider whether the firm in question makes a profit or loss and subsequently whether the firm meets or misses analysts' forecasts. Opportunistic managers, aware of analysts' considerations, act accordingly. For example, one specific strategy of earnings management that managers of loss firms use to clean up poor past performance for a fresh start, is asset write-offs (i.e., "big bath"). Shrewd managers tend to postpone major write-offs to the year they cannot report profits (Levitt, 1998; MacDonald, 1999; Byrnes and Henry, 2001).

Managers of profit firms behave differently to managers of loss firms because they take it for granted that analysts use different criteria to asses a write-off made by a profit firm than they do for a write-off made by a loss firm. For example, if the market anticipated a write-off due to losses in prior periods, the association between the annual returns and special items would be much weaker for a loss firm than for a profit firm. Alternatively, write-offs are frequently associated with the downward earnings management of loss firms since the managers of those firms who are already having a bad year would presumably wish to aggressively recognize future costs by clearing the decks. If investors expect a firm reporting a loss to take a big bath and subsequently report improved future financial performance, the association between the contemporaneous (future) return and the special item will be significantly negative.

Results suggest that a significant portion of write-offs is not recorded in a timely manner; moreover, the security market over the years preceding a write-off already takes into account any decline in asset value reflected in the write-off amount. In addition, the recognition of special items is less timely than that of other components of earnings. 


\section{Research Design}

This study begins by testing the timeliness of write-offs by first investigating the association between contemporaneous return and write-off amounts. Traditional accounting conventions of objectivity, verifiability, and/or conservatism conspire to delay the proper timing of a write-off. If the recognition of a write-off summarizes value relevant events of the past, the contemporaneous write-off should be significantly correlated with past returns, reflecting the fact that the security market was already aware of the information pertaining to the write-off in question.

Further, this study will take into consideration longer interval association between the asset write-offs and the security returns to examine the timeliness hypothesis. Prior studies suggest that timing errors in aggregate earnings become relatively less pronounced as the aggregation periods increase (Easton et al., 1992; Warfield and Wild, 1992). ${ }^{3}$ It follows that aggregation is likely to capture value relevant events which occurred in prior periods due to the write-offs' lack of timeliness.

Figure 1 shows the timeline of aggregation. The sample is partitioned into pre- and post-write-off periods to test the association between aggregate returns and aggregate write-offs. Write-off is recorded in fiscal period T.

\section{Figure 1}

\section{Time Line}

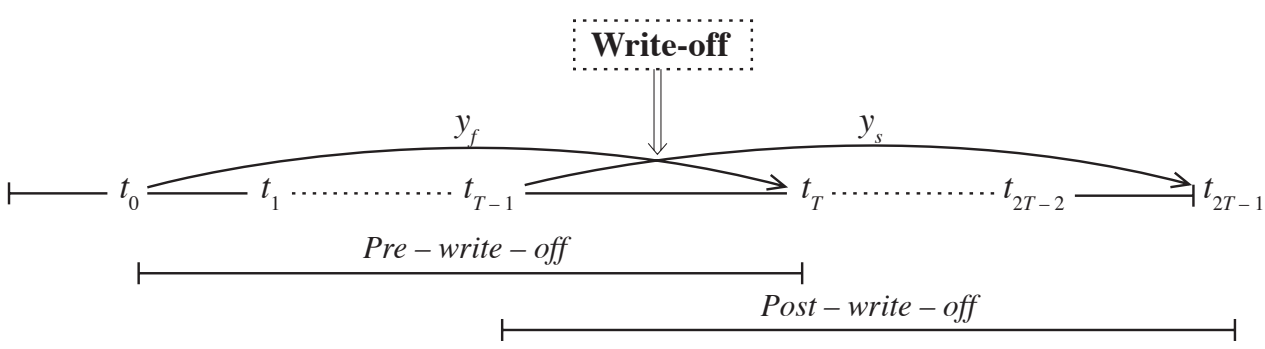

The pre-write-off period is from $t_{0}$ to $t_{T}$, and the post-write-off period is from $t_{T-1}$ to $t_{2 T-1}$. For example, five years is partitioned into two three-year sub-periods with the current year overlapping. For convenience, the aggregated data over the first three years is called "Pre-write-off", while the aggregated sample over the last three years is called "Post-write-off".

As a first step, annual data is used to test the association between returns and writeoffs. The presumption is that current earnings $\left(E_{t}\right)$ can be decomposed into earnings before special items $\left(E B S_{t}\right)$ and special items $\left(S I_{t}\right)$,

$$
E_{t}=E B S_{t}+S I_{t}
$$

\footnotetext{
${ }^{3}$ The meaning of timeliness of write-offs here is simply the extent to which contemporaneous market return is associated with current period write-off amounts. Please refer to Easton et al. (1992) for two error sources.
} 
$E B S_{t}$ can be defined as the sum of the earnings before special items value relevant for the current period $\left(E B S_{t}^{c}\right)$ and the earnings before special items value relevant for prior periods $\left(\sum_{\tau=-\infty}^{t-1} E B S_{\tau}^{c}\right)$. Similarly, $S I_{t}$ can be defined as the sum of the special items value relevant for the current period $\left(S I_{t}^{c}\right)$ and the special items value relevant for prior periods $\left(\sum_{\tau=-\infty}^{t-1} S I_{\tau}^{c}\right)$

$$
\begin{aligned}
& E B S_{t}=E B S_{t}^{c}+\sum_{\tau=-\infty}^{t-1} E B S_{\tau}^{c}+v_{t} \\
& S I_{t}=S I_{t}^{c}+\sum_{\tau=-\infty}^{t-1} S I_{\tau}^{c}+v_{t}
\end{aligned}
$$

Therefore, the association between returns and earnings is modeled as

$$
r_{t} \propto E B S_{t}^{c}+\sum_{\tau=-\infty}^{t-1} E B S_{\tau}^{c}+S I_{t}^{c}+\sum_{\tau=-\infty}^{t-1} S I_{\tau}^{c}
$$

If a write-off is recorded in a timely manner, it should be significantly associated with annual return, NOT with lagged returns (i.e., $\sum_{\tau=-\infty}^{t-1} S I_{\tau}^{c}=0$ ). In other words, if the write-off reflects changes that are perceived by the market during the fiscal year, this variable will have significant explanatory power for returns over the same period. Under the timeliness hypothesis, the association between aggregate return and aggregate writeoff for the pre-write-off period is not expected to be significantly higher than that for the post-write-off period. Alternatively, if the write-off amount is not recognized in a timely manner (in the sense that it recognizes value relevant events known to the market in previous periods), then the write-off should not be associated with annual return. However, the write-off amount should be significantly associated with lagged return(s) if the market was aware of the value relevant events in a prior period and incorporated them in the security prices (i.e., $\sum_{\tau=-\infty}^{t-1} S I_{\tau}^{c} \neq 0$ ). In these cases, the aggregation of writeoffs will synchronize with the timing difference. Because the write-off summarizes value relevant events of the past, the aggregate special item will provide statistically significant incremental explanatory power.

If accounting recognition of write-offs summarizes value relevant events of the past rather than providing information content relevant to future performance, the association between aggregate returns and aggregate write-offs for a past period will be significantly higher than for a future period. The association between aggregate return and aggregate write-off for a pre-write-off period should be significantly higher than that of a postwrite-off period.

In order to determine whether a write-off is recorded in a timely manner, annual stock returns are regressed on the components of earnings. The question of whether the inclusion of write-off amounts in earnings can provide a better summary of the information used by the security market is also addressed. To examine the hypothesis, estimations have been made of the coefficients using the following model:

$$
\begin{aligned}
& r_{i}=\alpha_{0}+\alpha_{1} \cdot x_{i}+\alpha_{2} \cdot L M V_{i}+\alpha_{3} \cdot F L V_{i}+\alpha_{4} \cdot M B_{i}+\varepsilon_{i} \\
& r_{i}=\beta_{0}+\beta_{1} \cdot \mathrm{z}_{i}+\beta_{2} \cdot s_{i}+\beta_{3} \cdot L M V_{i}+\beta_{4} \cdot F L V_{i}+\beta_{5} \cdot M B_{i}+\varepsilon_{i}
\end{aligned}
$$


where:

$r_{i}$ is the annual return for firm ${ }_{i}$ at time ${ }_{t}$;

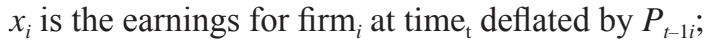

$Z_{i}$ is the earnings excluding special item for firm ${ }_{\mathrm{i}}$ at time $\mathrm{t}_{t}$ deflated by $P_{t-1 i}$;

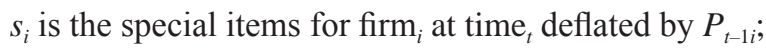

$M V_{i}$ is the logarithm of market value for firm ${ }_{i}$ at time t $_{t-1}$;

$F L V_{i}$ is the ratio of total assets to the book value of common equity firm at time $_{t-1}$;

$M B_{i}$ is the ratio of market to the book value of common equity for firm ${ }_{i}$ at time $e_{t-1}$;

$P_{i}$ is the security price for firm $i$ at time t- $_{1}$.

The coefficient $\beta_{2}$ captures the extent to which the increment to the write-off explains annual stock returns. If management has discretion to delay write-offs and write-offs could already have been perceived in the market, the write-off will not necessarily have explanatory power for the return in the same period. Large firms and small firms may have different tendencies in the timeliness of reporting component of earnings (Atiase, 1985; Atiase et al., 1987). Prior studies report that restructuring companies have higher financial leverage (Atiase et al., 2004). Both the size effects and the expected growth of companies are controlled for by including market value $(M V)$ and beginning-of-quarter market-to-book ratio $(M B)$, respectively. Beginning-of-year asset-to-book ratio $(F L V)$ is also accounted for to control for the financial leverage of the company.

One important difference between this study and prior studies is the aggregation of returns, earnings, and special items. The reasoning behind aggregation is to align accounting numbers and market value. The objective is to test the effect of a one-time large write-off on the market. Prior studies have demonstrated that the announcement of a write-off decision provokes mixed reactions in the market, partly due to a lack of timeliness. In the event that the write-off decision is significantly related to valuerelevant events occurring in prior periods, the association between the annual return and special items is less significant due to the discrepancy in recognition timing and measurement errors.

A central hypothesis of this paper is that as the test interval increases, value relevant events are more likely to be captured in the aggregate return. To examine this hypothesis, the model suggested by Easton et al. (1992) has been extended such that aggregate earnings are decomposed into aggregate earnings before special items (henceforth: aggregate earnings and aggregate special items).

To test the timeliness of asset write-offs, two sets of regression models are introduced for pre-write-off and post-write-off.

\section{Pre-write-off:}

$$
\begin{aligned}
& y_{f i}=\alpha_{0}^{f}+\alpha_{1}^{f} \cdot z_{f i}+\alpha_{2}^{f} \cdot L M V_{i}+\alpha_{3}^{f} \cdot F L V_{i}+\alpha_{4}^{f} \cdot M B_{i}+\varepsilon_{i} \\
& y_{f i}=\beta_{0}^{f}+\beta_{1}^{f} \cdot z_{f i}^{a}+\beta_{2}^{f} \cdot s_{f i}+\beta_{3}^{f} \cdot L M V_{i}+\beta_{4}^{f} \cdot F L V_{i}+\beta_{5}^{f} \cdot M B_{i}+\varepsilon_{i}
\end{aligned}
$$


where:

$y_{f i}$ is the aggregate return for firm ${ }_{i}$ for the pre-write-off;

$z_{f i}$ is the aggregate earnings for firm ${ }_{i}$ for the pre-write-off;

$z_{f i}^{a}$ is the aggregate earnings excluding special item for firm $\mathrm{i}_{\mathrm{i}}$ for the pre-write-off;

$s_{f i}$ is the aggregate special items for firm $i$ for the pre-write-off.

Coefficient $\beta_{2}^{f}$ captures the incremental explanatory power of aggregate write-offs to aggregate earnings for the pre-write-off period. If the coefficient $\beta_{2}$ in the regression model (1) is insignificant due to the lack of timeliness of the write-offs, it is plausible that the aggregate returns $\left(y_{f i}\right)$ over the longer period will capture the misalignment. If this turns out to be the case, the association between aggregate returns and aggregate write-offs will be significantly enhanced. In addition, the association between aggregate returns and aggregate special items for the pre-write-off period will provide evidence of the extent to which the write-off decisions are related to the value relevant events of the past.

\section{Post-write-off:}

$$
\begin{aligned}
& y_{s i}=\alpha_{0}^{s}+\alpha_{1}^{s} \cdot z_{s i}+\alpha_{2}^{s} \cdot L M V_{i}+\alpha_{3}^{s} \cdot F L V_{i}+\alpha_{4}^{s} \cdot M B_{i}+\varepsilon_{i} \\
& y_{s i}=\beta_{0}^{s}+\beta_{1}^{2} \cdot z_{s i}^{a}+\beta_{2}^{s} \cdot s_{s i}+\beta_{3}^{s} \cdot L M V_{i}+\beta_{4}^{s} \cdot F L V_{i}+\beta_{5}^{s} \cdot M B_{i}+\varepsilon_{i}
\end{aligned}
$$

where:

$y_{s i}$ is the aggregate return for firm ${ }_{i}$ for the post-write-off;

$z_{s i}$ is the aggregate earnings for firm ${ }_{i}$ for the post-write-off;

$z_{s i}^{a}$ is the aggregate earnings excluding special item for firm ${ }_{i}$ for the post-write-off;

$s_{s i}$ is the aggregate special items for firm ${ }_{i}$ for the post-write-off.

The coefficient $\beta_{2}^{s}$ captures the incremental explanatory power of aggregate writeoffs in relation to aggregate earnings for the post-write-off period. If a write-off decision is significantly related to value-relevant events occurring in a prior period, the association between the aggregation of special items and the aggregation of returns for the post-write-off period should not be as strong as that of past aggregation.

\section{Data, Sample Selection and Descriptive Statistics}

The sample data consists of annual earnings from 1961 to 2005. Earnings before extraordinary items, special items, dividends, number of shares, total assets, and prices are obtained from the COMPUSTAT annual file. All per share variables are adjusted for stock splits and stock dividends using Compustat adjustment factors. Altogether, this paper employs a sample of 5,658 firm-years. The sample selection rule requires six year data. Following the convention used by prior studies (Elliott and Shaw, 1988; Elliott and Hanna, 1996), a large write-off ("big bath") is defined as a special item that represents more than $1 \%$ of assets. Firm years are omitted if the 
firms in question have repeatedly taken large write-offs during the pre- or post-writeoff period. Firms repeatedly taking large write-offs are excluded since the research focus of this study is the one-time large write-off (however, observations with large write-offs solely in the test year are included). Firm years in the top and bottom $1 \%$ of return as well as special items of the write-off year are deleted as are firm years with positive aggregate special items. What remains of this write-off group is further partitioned into two groups: those whose special items are greater than $1 \%$ of total assets and those whose special items are less than $1 \%$ of total assets (i.e., small write-off: $-0.01 \leq \frac{S I_{t}}{T A_{t-1}}<0$; large write-off: $\frac{S I_{t}}{T A_{t-1}}<-0.01$ ).

Panel A of Table 1 shows the distribution of the sample by year. Consistent with prior studies, the number of firms reporting negative special items significantly increases during the sample period. The number of observations increases from a low of 11 in the 1963-1972 period to a high of 2,074 in the 1998-2003 period. About $36.7 \%$ of the observations are clustered from the late 1990s to the early 2000s. Only one year of the 40 sample years tested shows negative mean earnings before special items. ${ }^{4}$ Annual returns are distributed between a low of -0.029 in the 1968-1972 period and a high of 0.101 in the 1978-1982 period.

Descriptive statistics for variables used in subsequent regressions are reported in Panel B of Table 1. About $50 \%$ of the returns in the fiscal period in which write-offs are recorded are negative. In Panel B of Table 1, mean annual market return $\left(r_{t}\right)$ is around $5.0 \%$; mean annual earnings $\left(x_{t}\right)$ is 0.009 ; mean annual earnings before special items $\left(z_{t}\right)$ is 0.111 and mean annual special items $\left(s_{t}\right)$ is -0.102 . The average amount of the special items in the write-off year is $11.0 \%$ of total assets while the median value of the special items is $1.5 \%$ of total assets. The median values of the ratios are zero in both pre- and post write-off periods. For the pre-write-off period, the mean aggregate return is $47.4 \%$. The mean aggregate earnings is 0.834 while the mean aggregate earnings before special items is 0.943 . The mean aggregate special items is -0.108 .

Panel B of Table 1 documents regression variables for the post-write-off period. On average, firms perform well after recognizing special items. Mean aggregate return is $54.1 \%$; mean aggregate earnings is 0.450 while mean aggregate earnings before special items is 0.563 . Finally, mean aggregate special items is -0.113 .

\section{Empirical Results}

\subsection{Association between Aggregate Returns, Aggregate Earnings, and Aggregate Special Items}

Consistent with prior studies, annual regressions reveal that write-offs are not aligned with current market prices because they are recorded in the current period and because the associated decline in the market value of assets and security price occurred in an earlier period (Alciatore et al., 1998). ${ }^{5}$ To a large extent, declines in asset values are already reflected in the returns of previous periods. News of a write-off is not

\footnotetext{
${ }^{4}$ Not tabulated.

${ }^{5}$ Not tabulated.
} 
Table 1: Descriptive Statistics

Panel A: Descriptive Statistics for Variables by Year

\begin{tabular}{c|c|c|c|c|c|c|c|c}
\hline \multicolumn{2}{c|}{} & \multicolumn{2}{c|}{$r_{t}$} & \multicolumn{2}{c|}{$z_{t}$} & \multicolumn{2}{c}{$s_{t}$} \\
\hline Year & No. & $\%$ & Mean & Median & Mean & Median & Mean & Median \\
\hline $1963-1967$ & 11 & 0.2 & 0.229 & 0.101 & 0.089 & 0.099 & -0.003 & -0.003 \\
$1968-1972$ & 113 & 2.0 & -0.029 & -0.083 & 0.067 & 0.056 & -0.046 & -0.012 \\
$1973-1977$ & 434 & 7.7 & 0.027 & -0.050 & 0.128 & 0.136 & -0.155 & -0.066 \\
$1978-1982$ & 457 & 8.1 & 0.101 & 0.031 & 0.132 & 0.124 & -0.124 & -0.044 \\
$1983-1987$ & 639 & 11.3 & 0.026 & -0.029 & 0.071 & 0.063 & -0.109 & -0.036 \\
$1988-1992$ & 834 & 14.7 & 0.009 & -0.063 & 0.079 & 0.060 & -0.121 & -0.033 \\
$1993-1997$ & 1,096 & 19.4 & 0.089 & 0.035 & 0.116 & 0.066 & -0.098 & -0.030 \\
$1998-2003$ & 2,074 & 36.7 & 0.050 & -0.003 & 0.129 & 0.069 & -0.081 & -0.019 \\
\hline
\end{tabular}

$r_{t}$ is annual market return. $S_{t}$ is annual special items (COMPUSTAT \#17) deflated by $P_{t-1} \cdot z_{t}$ is annual earnings excluding special items (COMPUSTAT \#18-COMPUSTAT \#17) deflated by $P_{t-1}$. All variables are per share variables deflated by price and adjusted for stock splits and stock dividends.

Panel B: Descriptive Statistics for Variables

\begin{tabular}{|c|c|c|c|c|c|}
\hline & Mean & Std. Dev. & Q1 & Median & Q3 \\
\hline$r_{t}$ & 0.050 & 0.504 & -0.267 & 0.000 & 0.275 \\
\hline$x_{t}$ & 0.009 & 0.384 & -0.056 & 0.040 & 0.094 \\
\hline $\mathrm{z}_{\mathrm{t}}$ & 0.111 & 0.382 & 0.015 & 0.071 & 0.138 \\
\hline$S_{t}$ & -0.102 & 0.220 & -0.091 & -0.029 & -0.009 \\
\hline$\frac{S I_{t-2}}{T A_{t-3}}$ & 0.001 & 0.024 & 0.000 & 0.000 & 0.000 \\
\hline$\frac{S I_{t-1}}{T A_{t-2}}$ & 0.000 & 0.008 & 0.000 & 0.000 & 0.000 \\
\hline$\frac{S I_{t}}{T A_{t-1}}$ & -0.110 & 3.603 & -0.044 & -0.015 & -0.005 \\
\hline$\frac{S I_{t+1}}{T A_{t}}$ & 0.001 & 0.015 & 0.000 & 0.000 & 0.000 \\
\hline$\frac{S I_{t+2}}{T A_{t+1}}$ & 0.002 & 0.055 & 0.000 & 0.000 & 0.000 \\
\hline Pre-Write-Off & Mean & Std. Dev. & Q1 & Median & Q3 \\
\hline$y_{f}$ & 0.474 & 2.470 & -0.340 & 0.139 & 0.697 \\
\hline$z_{f}$ & 0.834 & 34.070 & 0.015 & 0.199 & 0.375 \\
\hline$z_{f}^{a}$ & 0.943 & 34.077 & 0.075 & 0.245 & 0.442 \\
\hline$S_{f}$ & -0.108 & 0.320 & -0.091 & -0.032 & -0.011 \\
\hline Post-Write-Off & Mean & Std. Dev. & Q1 & Median & Q3 \\
\hline$y_{s}$ & 0.541 & 1.846 & -0.212 & 0.259 & 0.831 \\
\hline$z_{s}$ & 0.450 & 5.305 & 0.004 & 0.195 & 0.392 \\
\hline$z_{s}^{a}$ & 0.563 & 5.472 & 0.069 & 0.234 & 0.456 \\
\hline$S_{s}$ & -0.113 & 0.323 & -0.096 & -0.032 & -0.010 \\
\hline
\end{tabular}

$r_{t}$ is contemporaneous market return calculated as $r_{t}=\frac{P_{t}+d_{t}-P_{t-1}}{P_{t-1}}$ where $P_{t}$ is the fiscal year end price (COMPUSTAT \#199). $x_{t}$ is the annual earnings excluding extraordinary items (COMPUSTAT \#18) deflated by $P_{t-1}$. SI is the annual special items (COMPUSTAT \#17). $s_{t}$ is $S I_{t}$ deflated by $P_{t-1}$.

$y_{f}\left(y_{s}\right)$ is the aggregate market return for the pre-write-off (post-write-off). $z_{f}\left(z_{s}\right)$ is the aggregate earnings including aggregate special items for the pre-write-off (post-write-off). $z_{f}^{a}\left(z_{s}^{a}\right)$ is the aggregate earnings excluding aggregate special items for the pre-write-off (post-write-off). $S_{f}\left(S_{s}\right)$ is the aggregate special items for the pre-write-off (post-write-off). All variables are per share variables deflated by the beginning-of-theperiod price and adjusted for stock splits and stock dividends. 
completely unexpected in the year of the actual write-off decision. ${ }^{6}$ As a result, there is a weak association between contemporaneous return and write-off. If the market anticipated the write-off sometime during the prior three years due to declining asset values over the same period, an efficient market would not behave in accordance with the notion that there is a strong association between a contemporaneous write-off and return because the decline in asset values was already incorporated in the price years before the delayed write-off.

The non-contemporaneous association between return and write-off due to a writeoff's lack of timeliness is captured by aggregating variables over a longer interval (Alciatore et al., 1998). The longer the interval, the more likely it is that value relevant events will be captured in earnings, special items, and returns.

Table 2 shows the aggregate data. Panel A and Panel B of Table 2 test the association between aggregate stock returns and aggregate earnings for the pre-write-off period. The coefficient on the aggregate special items $\left(\beta_{3}^{f}\right)$ is significantly negative. Panel A of Table 2 shows the association between aggregate returns $\left(y_{f}\right)$, aggregate earnings $\left(z_{f}^{a}\right)$, and aggregate special items $\left(s_{f}\right)$ when the special items are small negative. The coefficient on aggregate special items $(-0.921)$ is much smaller than that on the aggregate earnings (0.0002). There is significant improvement in adjusted $R^{2}$ for the regressions decomposing total aggregate earnings into aggregate earnings before special items and aggregate special items. Combined with annual regression, this result implies that small negative special items reflect past events. In this group, earnings are less informative about aggregate stock returns than special items.

Panel B of Table 2 shows the association between aggregate stock returns and aggregate earnings when the special items are materially large negative. There is significant improvement in adjusted $R^{2}$ for the regressions decomposing total aggregate earnings into aggregate earnings before special items and aggregate special items. The big bath sample shows higher adjusted $R^{2}(9.8 \%$ vs. $2.6 \%)$.

The association between aggregate special items and aggregate return is highly significant. As in the previous section, the coefficient on special items is negative and significantly smaller than that on the earnings (-1.949 vs. 0.068). The market seems to have anticipated the write-off sometime during last three years due to the declining value of assets over the same period. The market expected the write-offs sometime during the last three years and responded favorably when they actually occurred.

The explanatory power of special items in regard to the return is markedly improved by aggregation in the big bath sample. Panel B of Table 2 shows that the adjusted $R^{2}$ significantly increased from $1.7 \%$ to $9.8 \%$. Clearly, a big bath is not likely to be recorded in a timely manner, nor is it aligned with market returns.

Panels $\mathrm{C}$ and $\mathrm{D}$ of Table 2 show the regression results for the post-write-off sample. The association between aggregate returns and aggregate special items for the post-write-off period may explain the information content of the write-off. If the contemporaneous write-off has information content of future value, the association between aggregate returns and aggregate special items should be statistically significant.

\footnotetext{
${ }^{6}$ Untabulated partial rank correlation analysis of this study shows that the correlations between returns of prior years and special items are significantly positive (0.192). Interestingly, the correlation between special items and returns in the two periods preceding a write-off is significant $(0.180)$.
} 
Table 2: Regression of aggregate returns on aggregate earnings

Panel A: Pre-write-off $\left(-0.010 \leq \frac{S I_{t}}{T A_{t-1}}<0\right)$

\begin{tabular}{c|cccccccc}
\hline$n=2,233$ & Intercept & $z_{f i}$ & $z_{f i}^{a}$ & $s_{f i}$ & $L M V_{i}$ & $F L V_{i}$ & $M B_{i}$ & Adj. $R^{2}$ \\
\hline$y_{f i}$ & -0.104 & 0.0004 & & & 0.132 & 0.002 & 0.011 & 0.013 \\
$t$ & -0.77 & 0.45 & & & 5.52 & 0.44 & 1.13 & \\
\hline$y_{f i}$ & -0.101 & & 0.0002 & -0.921 & 0.126 & -0.0007 & 0.015 & 0.023 \\
$t$ & -0.75 & & 0.28 & -4.87 & 5.27 & -0.12 & 1.50 & \\
\hline
\end{tabular}

Panel B: Pre-write-off $\left(\frac{S I_{t}}{T A_{t-1}}<-0.01\right)$

\begin{tabular}{c|cccccccc}
\hline$n=3,430$ & Intercept & $z_{f i}$ & $z_{f i}^{a}$ & $s_{f i}$ & $L M V_{i}$ & $F L V_{i}$ & $M B_{i}$ & Adj. $R^{2}$ \\
\hline$y_{f i}$ & -0.280 & 0.078 & & & 0.148 & 0.0005 & 0.005 & 0.026 \\
$t$ & -2.61 & 6.61 & & & 6.52 & 0.39 & 1.74 & \\
\hline$y_{f i}$ & -0.581 & & 0.068 & -1.949 & 0.148 & -0.0003 & 0.006 & 0.098 \\
$t$ & -5.55 & & 5.99 & -15.93 & 6.77 & -0.21 & 2.04 & \\
\hline
\end{tabular}

Panel C: Post-write-off $\left(-0.01 \leq \frac{S I_{t}}{T A_{t-1}}<0\right)$

\begin{tabular}{c|cccccccc}
\hline$n=2,233$ & Intercept & $z_{f i}$ & $z_{f i}^{a}$ & $s_{f i}$ & $L M V_{i}$ & $F L V_{i}$ & $M B_{i}$ & Adj. $R^{2}$ \\
\hline$y_{f i}$ & 1.274 & 0.014 & & & -0.118 & 0.006 & -0.017 & 0.010 \\
$t$ & 8.43 & 2.16 & & & -4.43 & 0.97 & -1.48 & \\
\hline$y_{f i}$ & 1.275 & & 0.019 & 0.160 & -0.118 & 0.006 & -0.017 & 0.010 \\
$t$ & 8.44 & & 2.06 & 0.81 & -4.42 & 1.04 & -1.52 & \\
\hline
\end{tabular}

Panel D: Post-write-off $\left(\frac{S I_{t}}{T A_{t-1}}<-0.01\right)$

\begin{tabular}{c|cccccccc}
\hline$n=3,430$ & Intercept & $z_{f i}$ & $z_{f i}^{a}$ & $s_{f i}$ & $L M V_{i}$ & $F L V_{i}$ & $M B_{i}$ & Adj. $R^{2}$ \\
\hline$y_{f i}$ & 0.735 & 0.028 & & & -0.065 & 0.0003 & -0.001 & 0.009 \\
$t$ & 12.56 & 3.30 & & & -5.25 & 0.40 & -0.80 & \\
\hline$y_{f i}$ & 0.722 & & 0.027 & -0.021 & -0.064 & 0.0003 & -0.001 & 0.009 \\
$t$ & 11.60 & & 3.14 & -0.25 & -5.08 & 0.38 & -0.79 & \\
\hline
\end{tabular}

Note to Table 2:

$y_{f i}=\alpha_{0}^{f}+\alpha_{1}^{f} \cdot z_{f i}+\alpha_{2}^{f} \cdot L M V_{i}+\alpha_{3}^{f} \cdot F L V_{i}+\alpha_{4}^{f} \cdot M B_{i}+\varepsilon_{i}$

$y_{f i}=\beta_{0}^{f}+\beta_{1}^{f} \cdot z_{f i}^{a}+\beta_{2}^{f} \cdot s_{f i}+\beta_{3}^{f} \cdot L M V_{i}+\beta_{4}^{f} \cdot F L V_{i}+\beta_{5}^{f} \cdot M B_{i}+\varepsilon_{i}$

$y_{s i}=\alpha_{0}^{s}+\alpha_{1}^{s} \cdot z_{s i}+\alpha_{2}^{s} \cdot L M V_{i}+\alpha_{3}^{s} \cdot F L V_{i}+\alpha_{4}^{s} \cdot M B_{i}+\varepsilon_{i}$

$y_{s i}=\beta_{0}^{s}+\beta_{1}^{2} \cdot z_{s i}^{a}+\beta_{2}^{s} \cdot s_{s i}+\beta_{3}^{s} \cdot L M V_{i}+\beta_{4}^{s} \cdot F L V_{i}+\beta_{5}^{s} \cdot M B_{i}+\varepsilon_{i}$

where:

$y_{f i} \quad$ is the aggregate return for firm $i$ for the pre-write-off;

$z_{f i} \quad$ is the aggregate earnings for firm $i$ for the pre-write-off;

$z_{f i}^{a} \quad$ is the aggregate earnings excluding special items for firm ${ }_{i}$ for the pre-write-off;

$s_{f i} \quad$ is the aggregate special items for firm ${ }_{i}$ for the pre-write-off;

$y_{s i} \quad$ is the aggregate return for firm $i$ for the post-write-off; 
$z_{s i} \quad$ is the aggregate earnings for firm $_{i}$ for the post-write-off;

$z_{s i}^{a} \quad$ is the aggregate earnings excluding special item for firm ${ }_{i}$ for the post-write-off;

$s_{s i} \quad$ is the aggregate special items for firm ${ }_{i}$ for the post-write-off;

$M V_{i} \quad$ is the logarithm of market value for firm ${ }_{i}$ at time ${ }_{t-1}$;

$F L V_{i}$ is the ratio of total assets to the book value of common equity for firm ${ }_{i}$ at time $t_{t-1 ;}$

$M B_{i} \quad$ is the ratio of market to the book value of common equity for firm ${ }_{i}$ at time $t_{t-1}$.

Panel $\mathrm{C}$ of Table 2 tests the association between aggregate stock returns and aggregate earnings when the special items are small negative. The coefficient on the aggregate special items $\left(s_{s}\right)$ is insignificant. The explanatory power of the pre-writeoff $(2.3 \%)$ is greater than that of the post-write-off $(1.0 \%)$. Panel D of Table 2 shows the association between aggregate returns $\left(y_{s}\right)$, aggregate earnings $\left(z_{s}^{a}\right)$, and aggregate special items $\left(s_{s}\right)$ when the special items are materially large negative. Similar to the small write-off, the coefficient on the aggregate special items $\left(s_{s}\right)$ is insignificant.

Consistent with other literature on the subject, these results provide evidence that write-offs represent a de facto summary of past performance. The market could successfully see through the decline in asset value of the write-off companies. The association between aggregate special items and aggregate return is still significantly negative. Negative coefficients are discussed in the next section.

\subsection{Profit Firms and Loss Firms}

A number of articles in the financial press have alleged that investors first consider whether a firm makes a profit or loss before they assess the impact of a write-off. Many loss firms strategically take large write-offs in order to clean up poor past performance and start afresh. In doing so, they reveal their expectation of brighter future performance. Considering that profit and loss firms have different incentives for earnings management, a distinction should be made between the two in order to accurately assess the difference (if any) between the market's evaluations of the components of earnings for both. ${ }^{7}$ Thus, the sample used in this study is partitioned into profit and loss firms and then tested to account for the difference between a small write-off and a large write-off. Reported coefficients and adjusted $R^{2}$ s are consistent with those of prior studies.

Panel A of Table 3 documents the association between annual returns and components of earnings for profit firms. Coefficients on special items are positive. In general, the market does not show positive contemporaneous return to write-offs of profit firms.

Panel B of Table 3 shows the association between annual returns and components of earnings for loss firms. For loss firms, the coefficients on special items are significantly negative. Managers of loss firms use special items to communicate their private value relevant information, and the market values special items. To some degree, special items reflect value relevant information in the market for loss firms. As posited, a significant association between lagged returns and special items results in a weaker association

${ }^{7}$ Hayn (1995) reports that the association between annual stock returns and the level of earnings per share deflated by beginning stock price is much weaker for loss firms than for profit firms. The coefficient on earnings is almost zero for loss firms. 
between annual return and current special items. Untabulated correlation analysis indicates that both profit and loss firms have statistically significant correlations between lagged returns and special items. The correlation between the return of the two years preceding a write-off recognition and special items is also statistically significant.

Table 3: Regression of annual returns on annual earnings

Panel A: Profit Firms

\begin{tabular}{c|ccccccc}
\hline & Intercept & $z_{t i}$ & $s_{t i}$ & $L M V_{i}$ & $F L V_{i}$ & $M B_{i}$ & Adj. $R^{2}$ \\
\hline Small & 0.348 & 0.068 & 0.200 & -0.028 & 0.002 & -0.025 & 0.029 \\
$(n=1,934)$ & $(10.93)$ & $(2.30)$ & $(0.73)$ & $(-5.11)$ & $(1.11)$ & $(-4.17)$ & 0.018 \\
\hline Large & 0.267 & 0.086 & 0.190 & -0.031 & 0.008 & -0.006 & $(-1.27)$ \\
$(n=1,755)$ & $(7.84)$ & $(1.83)$ & $(2.12)$ & $(-5.09)$ & $(1.97)$ & \\
\hline
\end{tabular}

Panel B: Loss Firms

\begin{tabular}{c|ccccccc}
\hline & Intercept & $z_{t i}$ & $s_{t i}$ & $L M V_{i}$ & $F L V_{i}$ & $M B_{i}$ & Adj. $R^{2}$ \\
\hline Small & -0.011 & 0.206 & -2.329 & -0.042 & 0.0003 & 0.001 & 0.068 \\
$(n=300)$ & $(-0.15)$ & $(2.22)$ & $(-3.85)$ & $(-2.66)$ & $(0.15)$ & $(0.47)$ & \\
\hline Large & 0.021 & 0.102 & -0.097 & -0.047 & 0.0004 & 0.00003 & 0.021 \\
$(n=1,667)$ & $(0.55)$ & $(2.28)$ & $(-2.08)$ & $(-5.23)$ & $(1.22)$ & $(0.05)$ & \\
\hline
\end{tabular}

Notes to Table 3:

$r_{t i}=\alpha_{0}+\alpha_{1} \cdot z_{t i}+\alpha_{2} \cdot s_{t i}+\alpha_{3} \cdot L M V_{i}+\alpha_{4} \cdot F L V_{i}+\alpha_{5} \cdot M B_{i}+\varepsilon_{i}$

where:

Small $-0.01 \leq \frac{S I_{t}}{T A_{t-1}}<0 ;$

Large $\frac{S I_{t}}{T A_{t-1}}<-0.01$;

$r_{t i} \quad$ is the annual return for firm $i$ at time $t$;

$z_{t i} \quad$ is the earnings excluding special item for firm $i$ at time $e_{t}$ deflated by $P_{t-1}$;

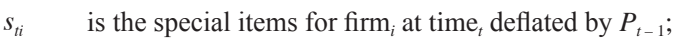

$M V_{i} \quad$ is the logarithm of market value for firm ${ }_{i}$ at time $e_{t-1}$;

$F L V_{i}$ is the ratio of total assets to the book value of common equity for firm at time $_{t-1}$;

$M B_{i} \quad$ is the ratio of market to the book value of common equity for firm ${ }_{i}$ at time $_{t-1}$;

$P_{t-1 i}$ is the security price for firm $i$ at time ${ }_{t-1}$.

The association between lagged returns and special items is even more prevalent for loss samples. In the case of big bath firms, special items are significantly negatively correlated with returns of the subsequent years $(-0.102,-0.066)$, evidence that many loss firms take write-offs for the sake of future returns. ${ }^{8}$ The result of the big bath sample is in line with prior findings in the sense that loss firms can boost future profits and substantially increase future returns by cleaning up the balance sheet because a significant portion of the decline in the value of assets, especially in loss firms, has already been captured in the market price of prior years. Recognition of special items

\footnotetext{
${ }^{8}$ In the case of profit firms, the correlation between special item and return for the following year for small write-off is positive but insignificant for large write-off. Not tabulated.
} 
is less timely than that of other components of earnings. In addition, special items are positively associated with annual stock returns for profit firms and negatively associated in the case of loss firms.

Table 4: Regression of aggregate return on aggregate earnings

Panel A: Profit Firms

\begin{tabular}{c|ccccccc}
\hline & \multicolumn{7}{|c}{ Pre-write-off } \\
\hline & Intercept & $z_{f i}$ & $s_{f i}$ & $M V_{i}$ & $F L V_{i}$ & $M B_{i}$ & Adj. $R^{2}$ \\
\hline Small & 0.075 & 0.00008 & -0.913 & 0.074 & -0.0003 & 0.115 & 0.023 \\
$(n=1,934)$ & $(0.47)$ & $(0.10)$ & $(-4.77)$ & $(2.74)$ & $(-0.05)$ & $(3.98)$ & 0.126 \\
\hline Large & 0.173 & 0.035 & -2.838 & -0.022 & -0.063 & 0.227 & $(7.57)$ \\
$(n=1,755)$ & $(0.17)$ & $(2.49)$ & $(-13.11)$ & $(-0.54)$ & $(-2.32)$ & \\
\hline
\end{tabular}

\begin{tabular}{c|ccccccc}
\hline & \multicolumn{7}{|c}{ Post-write-off } \\
\hline & Intercept & $z_{s i}$ & $s_{s i}$ & $M V_{i}$ & $F L V_{i}$ & $M B_{i}$ & Adj. $R^{2}$ \\
\hline Small & 1.729 & 0.017 & 0.148 & -0.160 & 0.005 & -0.091 & 0.018 \\
$(n=1,934)$ & $(9.46)$ & $(1.72)$ & $(0.71)$ & $(-5.05)$ & $(0.68)$ & $(-2.70)$ & 0.036 \\
\hline Large & 1.224 & 0.045 & 0.212 & -0.121 & 0.007 & -0.003 & $(-0.29)$ \\
$(n=1,755)$ & $(14.21)$ & $(3.22)$ & $(2.23)$ & $(-7.70)$ & $(0.65)$ & \\
\hline
\end{tabular}

Panel B: Loss Firms

\begin{tabular}{c|ccccccc}
\hline & \multicolumn{7}{|c}{ Pre-write-off } \\
\hline & Intercept & $z_{f i}$ & $s_{f i}$ & $M V_{i}$ & $F L V_{i}$ & $M B_{i}$ & Adj. $R^{2}$ \\
\hline Small & -1.584 & 0.431 & -9.219 & 0.112 & -0.013 & 0.013 & 0.124 \\
$(n=300)$ & $(-2.30)$ & $(4.34)$ & $(-5.16)$ & $(1.90)$ & $(-1.56)$ & $(1.32)$ & 0.116 \\
\hline Large & -0.578 & 0.049 & -1.122 & 0.094 & 0.0003 & 0.002 & $(1.49)$ \\
$(n=1,667)$ & $(-8.20)$ & $(1.16)$ & $(-13.02)$ & $(5.28)$ & $(0.48)$ & \\
\hline
\end{tabular}

\begin{tabular}{c|ccccccc}
\hline & \multicolumn{7}{|c}{ Post-write-off } \\
\hline & Intercept & $z_{s i}$ & $s_{s i}$ & $M V_{i}$ & $F L V_{i}$ & $M B_{i}$ & Adj. $R^{2}$ \\
\hline Small & 0.769 & 0.436 & -2.237 & -0.154 & 0.010 & -0.004 & 0.072 \\
$(n=300)$ & $(3.57)$ & $(3.89)$ & $(-1.84)$ & $(-3.27)$ & $(1.59)$ & $(-0.60)$ & 0.009 \\
\hline Large & 0.703 & 0.011 & -0.329 & -0.131 & 0.0002 & -0.001 & $(-0.44)$ \\
$(n=1,667)$ & $(4.47)$ & $(0.64)$ & $(-1.56)$ & $(-3.49)$ & $(0.16)$ & \\
\hline
\end{tabular}

Notes to Table 4:

$y_{f i}=\alpha_{0}^{f}+\alpha_{1}^{f} \cdot z_{f i}+\alpha_{2}^{f} \cdot s_{f i}+\alpha_{3} \cdot L M V_{i}+\alpha_{4} \cdot F L V_{i}+\alpha_{5} \cdot M B_{i}+\varepsilon_{i}$

$y_{s i}=\alpha_{0}^{s}+\alpha_{1}^{s} \cdot z_{s i}+\alpha_{2}^{s} \cdot s_{s i}+\alpha_{3} \cdot L M V_{i}+\alpha_{4} \cdot F L V_{i}+\alpha_{5} \cdot M B_{i}+\varepsilon_{i}$

where:

Small $-0.01 \leq \frac{S I_{t}}{T A_{t-1}}<0$;

Large $\frac{S I_{t}}{T A_{t-1}}<-0.01$; 
$y_{f i}$ is the aggregate return for firm ${ }_{i}$ for the pre-write-off;

$y_{s i}$ is the aggregate return for firm $_{i}$ for the post-write-off;

$z_{f i}$ is the aggregate earnings for firm ${ }_{i}$ for the pre-write-off;

$z_{s i}$ is the aggregate earnings for firm $_{i}$ for the post-write-off;

$s_{f i}$ is the aggregate special items for firm $_{i}$ for the pre-write-off;

$s_{s i}$ is the aggregate special items for firm $_{i}$ for the post-write-off

Table 4 documents the association between aggregate returns and aggregate components of earnings for both profit firms and loss firms. Panel A of Table 4 documents the association between aggregate returns and aggregate special items for profit firms. Worth noting is that the coefficients on special item are negative for both small write-off (-0.913) and large write-off (-2.838). In the pre-write-off period, the coefficient on earnings for small write-off is significantly negative. Consistent with various indicators in the financial press, investors seem to view write-offs for profit firms positively given that those firms will almost always show increased future profit. Another explanation is that management of write-off firms behave opportunistically to reduce excessive earnings while the market responds positively to the write-offs. After all, the market has already incorporated the write-off news in prior periods.

Panel B of Table 4 documents the association between aggregate returns and aggregate special items for loss firms. In all partitions, coefficients on special items are negative. Pre-write-off regression shows that coefficients on special items for both small (-9.219) and large (-1.122) write-offs are negative. In the post-write-off period, coefficients on special item are weakly negative. This is consistent with the result of prewrite-offs in the sense that the market has already adjusted for the write-off and rewards the write-off decision accordingly. If loss firms take a big bath with some slack, they can significantly improve future earnings. ${ }^{9}$ The results lend support to analysts who maintain that "the bigger the bath, the better." Loss firms can boost future profits and substantially increase future returns by cleaning up their balance sheets. Firms disclose an expected large write-off through various communication channels, while the market has long before incorporated the expected write-offs into the security's price. In this way, many loss firms take write-offs for the sake of the future returns.

\section{Concluding Remarks}

Many of the findings of this study bolster the conclusions of earlier studies, in particular that (1) for profit firms, the special item is positively correlated with contemporaneous return and has an even greater correlation with lagged returns, and that (2) loss firms can boost future profits and substantially increase future returns by cleaning up the balance sheet (Pourciau, 1993).

The main purpose of this study is to assess whether the association of asset writeoffs and the security markets is well aligned. It turns out that it is not; however, by aggregating the components of earnings, the explanatory power of those respective components is significantly enhanced vis-à-vis security market returns. Nowhere is

\footnotetext{
${ }^{9}$ Atise et al. (2004) documented that firms with losses in restructuring years can significantly improve their earnings in subsequent years.
} 
this more in evidence than in the sub-samples of profit firms and loss firms where the aggregate write-off amounts have statistically significant incremental explanatory power for the aggregate returns of profit firms and loss firms. Aggregate write-off amounts have weaker explanatory power for the aggregate returns over the future period. Put another way, contemporaneous write-offs summarize underlying economic events of the past but provide little or no indication of future performance.

Timing issues related to write-offs have a lot to do with prevailing regulations and overall business climate, neither of which remains static over time. It would be worthwhile to conduct a longitudinal analysis to gauge the depth of the influence of regulations on write-off decisions by, say, tracking the historic change of timeliness both before and after the Sarbanes-Oxley Act of 2002. Another extension would be to investigate companies with habitual write-offs. This research limited its scope of enquiry to the company with a large one-time write-off. Granted that economic events are rarely viewed in isolation, one must accept that the same company, should it have had a history of large write-offs, would have been treated quite differently than it would have had it only the one write-off on its record.

\section{References}

Alciatore, M., C. Dee, P. Easton, and N. Spear, 1998, “Asset Write-Downs: a Decade of Research", Journal of Accounting Literature 17, 1-39.

Alciatore, M., P. Easton, and N. Spear, 2000, "Accounting for the Impairment of Longlived Assets: Evidence from the Petroleum Industry", Journal of Accounting and Economics 29, 151-172.

Atiase, R., 1985, "Predisclosure Information, Firm Capitalization, and Security Price Behavior around Earnings Announcements", Journal of Accounting Research 23 (18), 21-36.

Atiase, R., L. Bamber, and S. Tse, 1987, "Timeliness of Financial Reporting, the Firm Size Effect, and Stock Price Reactions to Annual Earnings Announcements", Contemporary Accounting Research 5 (2), 526-552.

Atiase, R., D. Platt, and S. Tse, 2004, "Operational restructuring charges and postrestructuring performance", Contemporary Accounting Research 21 (3), 493-522.

Bartov, E., F. Lindahl, and W. Ricks, 1998, "Stock Price Behavior Around Announcements of Write-offs", Review of Accounting Studies 3 (4), 327-346.

Brown, L., 1999, "Managerial Behavior and the Bias in Analysts' Earnings Forecasts", Working paper, Georgia State University.

Bunsis, S., 1997, "A Description and Market Analysis of Write-off Announcements", Journal of Business, Finance, and Accounting 24, 1385-1399.

Byrnes, N. and D. Henry, 2001, "Confused about Earnings?", Business Week 76, Nov 28/2001, Issue 3759.

Chaney, P.K., C.E. Hogan, and D.C. Jeter, 1999, “The Effect of Reporting Restructuring Charges on Analysts' Forecast Revision and Errors", Journal of Accounting and Economics 27, 261-284. 
Clifford, L., 2001, "Is Your Stock Addicted to Write-Offs?”, Fortune, 98, Volume 143, Issue 7.

Collins, D.W. and S. Henning, 2000, “Are Write-downs of Discontinued Operations' Assets Timely?", University of Houston and Southern Methodist University, Working Paper.

DeGeorge, F., J. Patel, and R. Zeckhauser, 1999, "Earnings Management to Exceed Thresholds", Journal of Business 72(1), 1-33.

Easton, P., T. Harris, and J. Ohlson, 1992, “Aggregate Accounting Earnings can Explain Most of Security Returns", Journal of Accounting and Economics 15, 119-142.

Elliott, J. and J. Hanna, 1996, "Repeated Accounting Write-offs and the Information Content of Earnings", Journal of Accounting Research 34, 135-155.

Elliott, J. and W.H. Shaw, 1988, "Write-offs as Accounting Procedures to Manage Perceptions", Journal of Accounting Research 26, 91-126.

Francis, J., D. Hanna, and L. Vincent, 1997, "Causes and Effects of Discretionary Asset Write-offs", Journal of Accounting Research 34, 117-134.

Hayn, C., 1995, “The Information Content of Losses", Journal of Accounting and Economics 20, 125-153.

Heflin, F. and T. Warfield, 1997, "Managerial discretion in accounting for asset writeoffs", University of Wisconsin-Madison, Working Paper.

Hogan, C. and D. C. Jeter, 1998, “The Information Content of Restructuring Charges: A Contextual Analysis", Vanderbilt University, Working Paper.

John, K. and E. Ofek, 1995, “Asset Sales and Increase in Focus", Journal of Financial Economics 37, 105-126.

Levitt, A., 1998, "Remarks by Chairman Arthur Levitt of Securities and Exchange Commission, "The Number Game"", NYU Center for Law and Business, New York, N.Y., http://www.sec.gov/news/speech/speecharchive/1998/spch220.txt

MacDonald, E., 1999, "SEC Seeks to Curb Abuses of Charges for Restructurings," The Wall Street Journal B, Nov. 26, 1999.

Pourciau, S., 1993, "Earnings Management and Nonroutine Executive Changes," Journal of Accounting and Economics 16, 317-336.

Strong, J. and J. Meyer, 1987, “Asset Write-Downs: Managerial incentives and Security Returns", Journal of Finance 42, 643-661.

Warfield, T.D. and J.J. Wild, 1992, “Accounting Recognition and the Relevance of Earnings as An Explanatory Variable for Returns", The Accounting Review 67, 821 -842 .

Wilson, G., 1996, “Discussion Write-offs: Manipulation or Impairment?”, Journal of Accounting Research 34, 171-177.

Zucca, L. and D. Campbell, 1992, “A Closer Look at Discretionary Write-downs of Impaired Assets,” Accounting Horizons September, 30-41. 